\title{
3 \\ Women's Wealth and Moral Economies among the Maisin in Collingwood Bay, Papua New Guinea
}

\author{
Anna-Karina Hermkens
}

\section{Introduction}

The repetitive beat of the kundu drums, carrying the men's chanting, echoes through the hills and fjords of Tufi as Maisin dancers, dressed up in their colourful regalia, make their way to the mission station field. The audience's gaze moves between the strikingly vivid display of red and black designs that are painted on the white tapa loincloths that both male and female dancers wear, and the elaborate male headdresses swaying back and forth to the beat of the music (Figure 12). While the men's long and narrow strip of tapa loincloth (koefi) allows them to move freely and sway their entire bodies back and forth, women's movement is restricted and confined by their rectangular-shaped tapa loincloths (embobi), which are tightly wrapped around their hips, covering their thighs and knees. In contrast to the men, they keep their upper bodies still and with great subtlety move their hips while shuffling their naked feet forwards and backwards. Although dancing as a group, or rather as a tribe, the dancers actually dance together in multiple sets of same-sex pairs, with each individual dancer's gender and clan identity being visualised and embodied through 
the designs painted on their tapa loincloths and the specific shells and feathers they wear (Figure 13). Dancing in utter concentration for hours and hours, the repetitive movements and the monotone music induce an almost trance-like state. The dancers transcend time and place as they address their ancestors, their ancestors' journeys, wars, land claims, as well as past loves and romances, through the tapa designs, dances and songs. By means of their clothing, the dancers have transformed from ordinary men and women into withdrawn ancestral figures of splendour, beauty and restraint (Hermkens 2007; see also Schieffelin 1976: 1-25). ${ }^{1}$ At the same time this performance is a performative act (Lambek 2013) that conveys, embodies and constitutes an overabundance of values that are both ethical and economical, and related to the production or making of tapa, and its uses as a garment, gift and commodity.

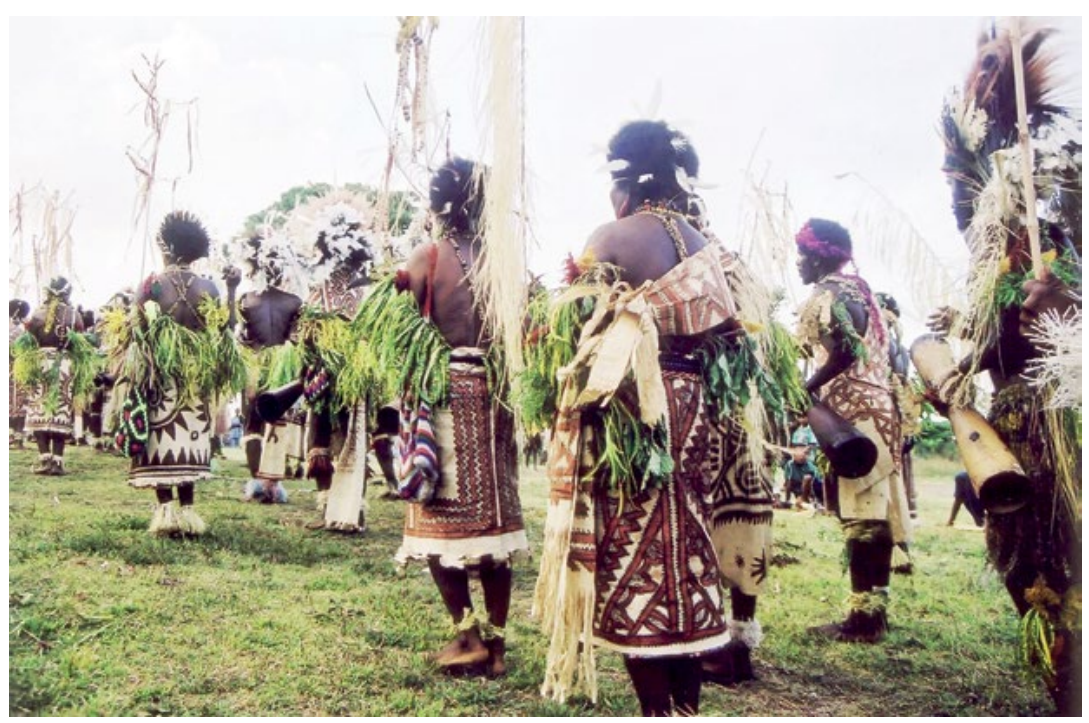

Figure 12. Maisin dancers wearing their tapa loincloths at a church festival held near Tufi

Source. Photographed by Anna-Karina Hermkens, 30 September 2001

1 But it's not only for the wearers that the performance of tapa and their decorated body brings about an experiential dimension. The audience is likewise drawn into this powerful display of concentration, strength and beauty. However, originating from different tribes, they repeatedly try to lift the invocation by drawing the dancers back to the present, eliciting loss of concentration and thereby mistakes through joking and insulting comments. 


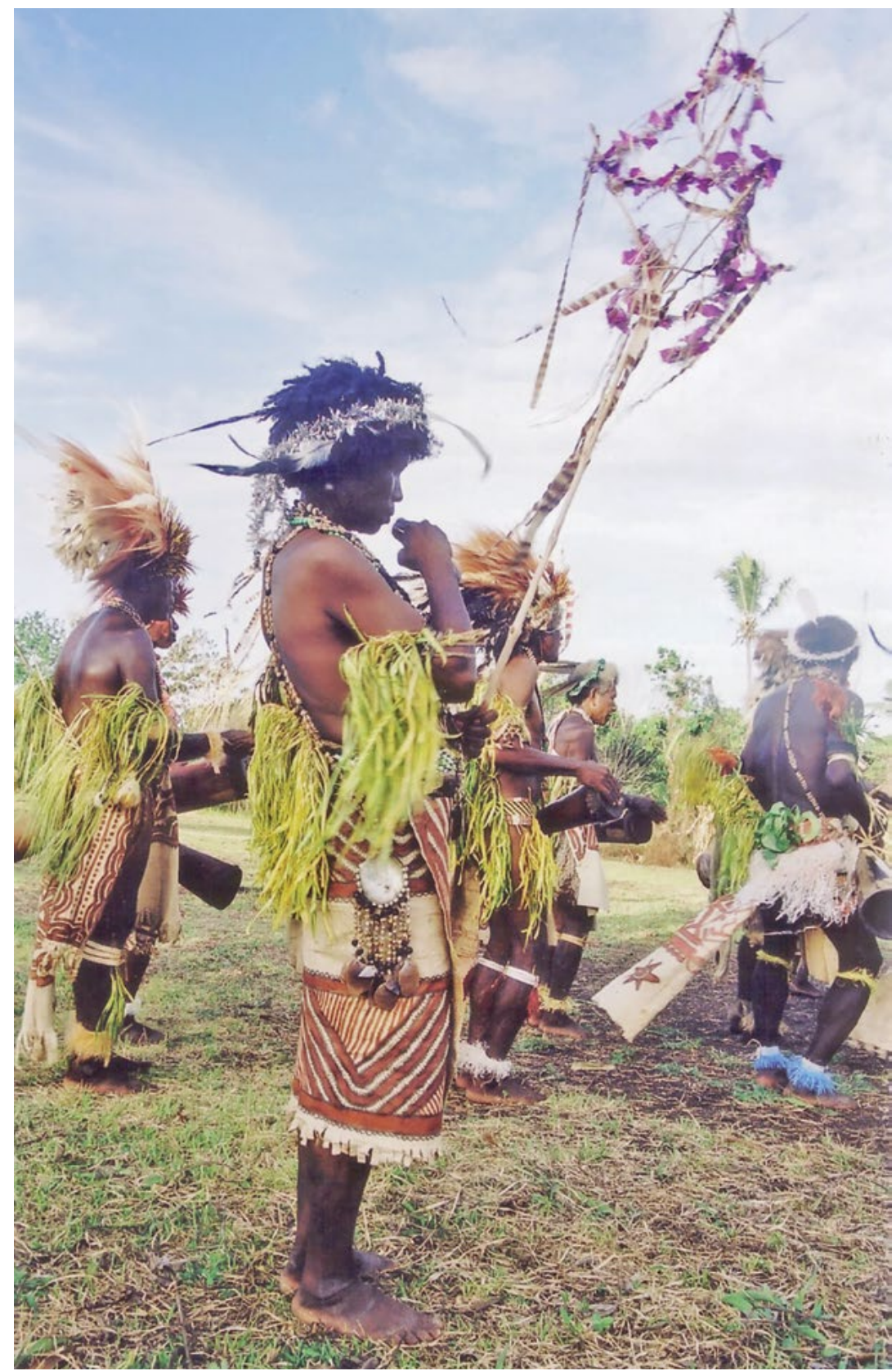

Figure 13. Maisin dancers wearing their regalia and tapa cloths decorated with clan designs

Source. Photographed by Anna-Karina Hermkens, 30 September 2001 
The tapa cloths worn by the male and female Maisin dancers are not just used as garments during Anglican Church festivals as the one described above. Tapa, which is made and painted by Maisin women, features in Maisin economic, political, social and spiritual life as an object of wealth that is both 'alienable' and 'inalienable' (Weiner 1992). In the past, tapa was used as a blanket, wrapped around sago in order to transport it from the gardens to the village, and deceased people were first wrapped in mats and subsequently covered with a piece of tapa before being buried. ${ }^{2}$ More recently, sold at national and international markets as an object of ethnic art, tapa contributes significantly to Maisin livelihood. This alienable tapa cloth is also used in barter and ceremonial exchanges. Today, Maisin women are the main producers of tapa in the region and beyond; many neighbouring and more distant cultural groups who have stopped manufacturing barkcloth, but also groups who have lost or have no tradition of wearing barkcloth, wear Maisin tapa as a 'traditional' garment during festivities and cultural performances (see also Bonshek this volume). In addition to local, regional and international transactions with this alienable tapa cloth, tapa, decorated with clan designs, features as inalienable clan property. Unless it is utilised as a way to cement relationships, it may not be given away outside the clan, or sold. This inalienable cloth is often used as festive and ceremonial dress, playing an important role in church festivals and life-cycle rituals, such as marriage and mourning. In these contexts, the wearing and giving of tapa are embodied performances (Hermkens 2010) that convey and, at the same time, constitute beliefs and values about gender relations and identity, mediating relations between the individual and the social, and connecting the living with the ancestors, God and the Church.

These various properties, meanings and values of tapa are also discernible in the eastern Pacific, where tapa is equally made by women, and features as a garment and gift during various ceremonies and rituals (Addo 2007, 2013, this volume; Jolly 2008; Veys this volume; and Young Leslie and Addo 2007). As the editors of a special volume on Pacific textiles point out, Pacific textiles are surprisingly durable in their sociality. 'Through their production, deployment, and malleable physical form, they lend themselves to metaphor', and they are wonderful mediums for pragmatic creativity (Young Leslie and Addo 2007: 16). Strikingly, most of the anthropological studies on tapa deal with tapa from the eastern Pacific

2 Today pieces of cotton cloth have replaced the tapa used to cover the deceased's body. 
or, when focusing on Melanesia, barkcloth made by men, or tapa that is used in male-dominated rituals (for example, Fajans 1997; Meyer 1992; Williams 1928, 1940). It seems that tapa produced by Papua New Guinean women has been neglected by anthropological scholars, despite the fact that Annette Weiner (1992: 47) already elucidated the importance of cloth as an essential form of material wealth and the locus of women's strategies, power and agency. In this chapter, I add to this knowledge and deal with the relationship between Melanesian tapa as a form of 'women's wealth', and its use in gift and commodity exchanges among the Maisin of Oro province in Papua New Guinea (Map 2).

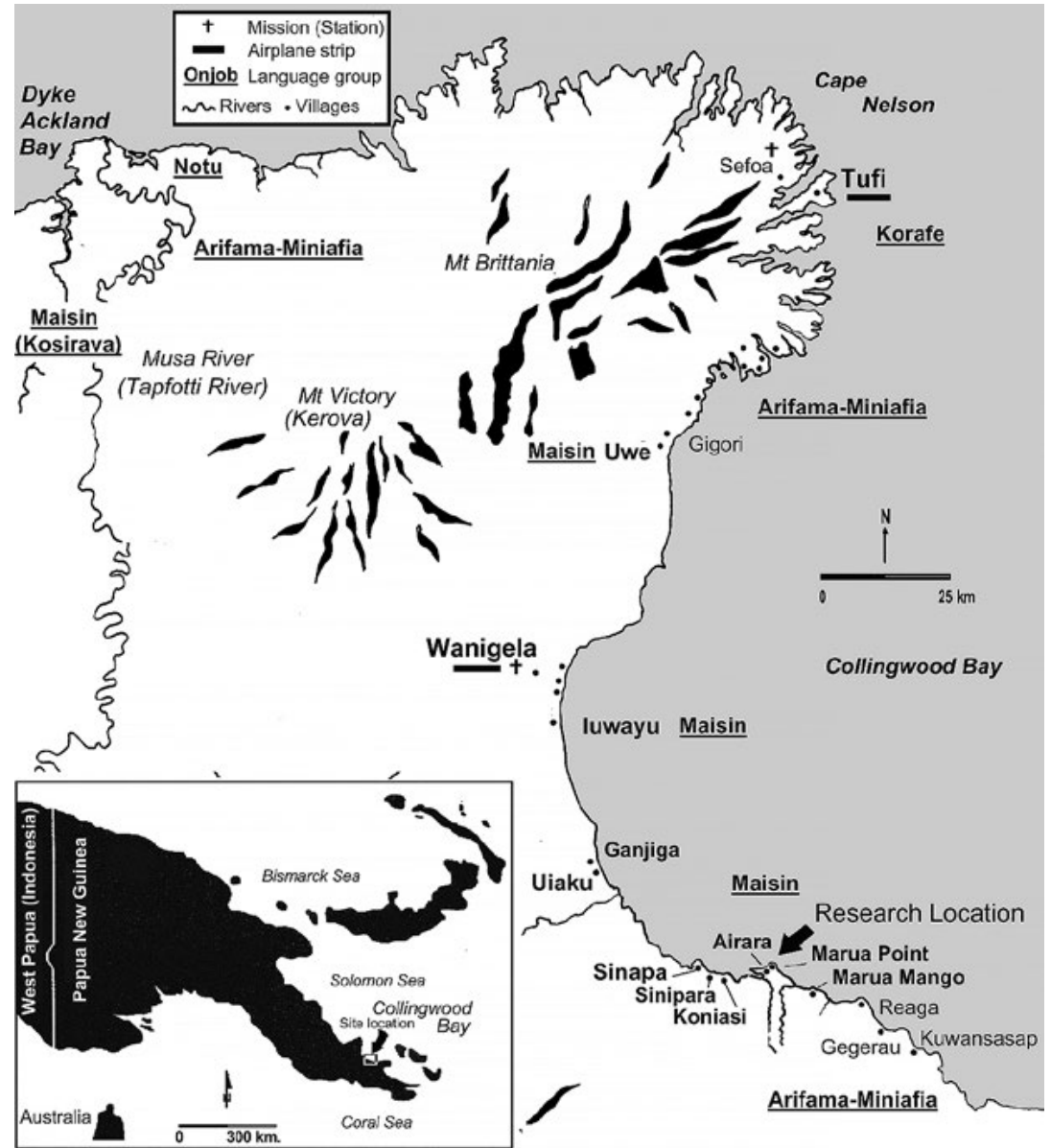

Map 2. Collingwood Bay, Oro Province, Papua New Guinea

Source. Drawn by Anna-Karina Hermkens 
Among the Maisin people, as elsewhere in the Pacific, practices of decorating and performing the body during rituals and festivals, such as the one described earlier, are intertwined with practices of giving. In fact, the presentation of the decorated body and the presentation of tapa as a gift, are performances that engender personhood and social (kinship) identities, as well as relationships. Maisin dancers embody and display their gendered clan and Maisin identity, at the same time as they impart a bit of themselves through their performance and the tapa they give in return for the food and hospitality they receive from their hosts. Also in ceremonies, such as in marriage and mourning rituals, the intimate connection between decorating and performing the body, the exchange of objects like tapa, and the establishment of social personhood and the nurturing of relationality is profound (Hermkens 2010). In these instances, the main purpose of tapa, both as dress and as gift, is the establishment and maintenance of social relationships. This implies that people's identities are not only relational, but also 'distributed' in both their social and material surroundings. The constitutive outside encompasses other people, ancestors (see also Knauft 2002: 27) and materialities such as tapa. This concurs with Marilyn Strathern's observation that objects circulate within relationships in order to make relations in which objects can circulate (1990: 221). Inspired by the influential work of Marcel Mauss and Karl Marx, Chris Gregory advocated a firm relationship between personhood and modes of exchange, arguing that things and people assume the social form of persons in a gift economy, while they assume the social form of objects in a commodity economy (Gregory 1982: 41). Gregory acknowledged that reality is much more complex and diverse and that, for example, a single object can assume different social forms depending upon the context (see also Godelier 1973: 128; 1999). Drawing on the work of James Carrier (1995) and Edward LiPuma (1998), Rachel Morgain and John Taylor in an edited volume on Gender and Person in Oceania (Hermkens, Taylor and Morgain 2015) remind us that this copresence of gift and commodity exchange demands 'careful revelation of how these forms of exchange mutually articulate and how they crystallise and engender different dynamics of sociality and agency' (Morgain and Taylor 2015: 3). The copresence of gift and commodity exchange is visible among the Maisin, who use tapa both as a gift and a commodity in various types of exchanges and transactions. Margaret Jolly (2015) argues that we should better understand and appreciate this copresence and, what she terms, the creolisation of gifts and commodities. 
I will build upon these insights by focusing on how value is created in exchanging tapa as a gift and commodity. But I will first unravel how value is created in the processes of making, as this shows how value, gendered personhood, relationality and action are interlinked, not just in the exchange of objects, but also in their creation and their use in performances such as church festivals and exchanges. As has been argued by Thomas Widlok (2013: 13) and others (for example, Graeber 2001: 4; Lambek 2013), action, performativity and agency are very much part of how value is created. I will start by briefly elucidating the intimate correspondence between Maisin women and tapa, and how they are part of each other's substance. This will be followed by an overview of Maisin exchanges and an analysis of what happens when these imbued or saturated cloths are exchanged during life-cycle rituals, and bartered or sold as commodities.

\section{Women making tapa}

Among Maisin, women are traditionally responsible for both the manufacture of barkcloth and the application of black designs and red pigment on the tapa surface. The importance of tapa for Maisin people is reflected in the statement 'Maisin is tapa'. Moreover, because of its importance for Maisin livelihood and identification, everybody agrees that all women, even those married into Maisin from the outside, have to learn how to make and design it. Although each woman has her own style of design, Maisin tapa is always clearly identifiable, as women remain within the boundaries of what is regarded as good Maisin tapa. Aesthetic concepts of what makes a good tapa and a good design are mainly confined to the texture of the tapa and the structure of the design - it must consist of at least four lines_ and care is taken not to spill red pigment outside the black lines. Individual preferences for the work of particular women do exist, but both men and women will always stress that all Maisin women are capable tapa makers, drawers and painters.

However, the intricacy of making, designing and painting tapa becomes clear when adult women married into Maisin, or visitors like me, start learning to make tapa. As I witnessed and experienced, making and designing Maisin tapa requires technical and creative skills (seraman), strength, as well as knowledge (mon), which are part of Maisin personhood 
and sociality, and thus not easily or quickly learned. ${ }^{3}$ In fact, these skills, attributes and knowledge are most efficacious when embodied from a young age onwards. The particular way of beating the inner bark of the paper mulberry tree (Broussonetia papyrifera, locally called wuwusi) into pliable tapa cloth; the techniques associated with designing the meandering black lines and their intricate application on, and correspondence with, the rough tapa surface; and, finally, the intimate connection between the red pigment (dun) with women's bodies and blood, all require and at the same time produce what Marcel Mauss (1979: 97-123) referred to as 'gendered body techniques'. As I argue and show elsewhere (Hermkens 2013, 2015: 13), these body techniques, and the way tapa continues to shape and constrain female bodies when worn, show how the gendered roles women are expected to perform, and are continuously inscribed and embodied through the reiteration of nondiscursive practices such as beating, designing and wearing tapa. These practices do not just interact with but correspond to the tapa surface. According to Tim Ingold (2013: 105), correspondence implies a sentient back and forth movement in time that creates something else. The rather coarse fibrous texture of the barkcloth influences how the lines can be applied, resisting some movements and facilitating others. The whole practice of making and drawing tapa is thus part of a process in which the women artists are participants (see also Ingold 2013: 21). In addition to the physical correspondence between women and tapa in acts of making and wearing, making tapa has specific cosmological associations and is related to notions about reproduction, childbirth and creation, which are important in defining womanhood (Hermkens 2015; see also Schneider 1987: 413). This interplay between cosmology, gender and cloth has also been noted in other parts of Oceania (for example, Colchester 2003: 9; Young Leslie and Addo 2007: 19). In many contexts, cloth production and utilisation are closely associated with mothers and the love and responsibilities that they devote to their children and extended families (Addo 2007, 2013, this volume; Young Leslie and Addo 2007: 18).

Monica Taniova, at the time of my fieldwork a cheerful 35-year-old mother of five children with a beautifully tattooed face (Figure 14), ${ }^{4}$ was one of the younger, acknowledged good tapa makers among the Maisin.

3 Personhood among Maisin is referred to as mon seraman, just as the skills and attributes needed to make Maisin tapa. In a recent article (Hermkens 2015), I analyse in more detail this intimate connection between Maisin tapa, womanhood and notions of the person and self.

$4 \quad$ Fieldwork among the Maisin people took place between 2001 and 2002 and in 2004. 
Her proficiency with the nasa brush surpassed the skills of many other women, drawing straight and almost perfectly symmetrical designs on the fibrous and somewhat rough tapa surface. Monica loved drawing barkcloth designs. While other women sometimes tended to make quick drawings because of the monetary necessity to make tapa, Monica always placed much effort and imagination into her designs. If it were up to her, she would spend even more time making tapa. As she said, 'I really like drawing and painting, and I would like to do this the whole day. In fact, I used to do that, but now I have plenty work to do for my parents-inlaw, husband and children' (interview with Monica, Airara village, 2001). This statement reveals the impact of virilocal residency as well as the many responsibilities tapa makers like Monica face. Monica cannot depend on her brothers and sisters to provide her with help or foodstuffs. Because she was born in Ganjiga village, her parents and brothers are two hours' sailing distance from her current residence in Airara, where she lives with her husband, her children and her parents-in-law in a large house on the edge of the village, which is part of her husband's clan. Being responsible for the maintenance of the house and her husband's garden, and especially for the feeding of both her own family and her in-laws, she has little time to spend on making tapa. In fact, she has to carefully balance her time and activities to be able to make, design and finally paint the cloth.

Monica always prepared and beat her tapa bark on the platform underneath her husband Clifford's house, which is in fact her working area. While her in-laws, and sometimes her children and husband, often rested in the large elevated shelter (barè-barè) next to the house, I would frequently find Monica working in 'her area', where she would also do the cooking. Monica's youngest child, Christina, would often sit with her underneath the house or play with other children in the area while her older sisters and brother were at school. Watching her mother making and designing tapa means that Christina is socialised in the intricacies of making tapa from a very young age, just as Monica was. As the latter recalls:

My mother Stella taught me how to beat and design tapa. First, I learned how to beat tapa; the drawing of the designs, I learned somewhat later. When I was about 14 years old, I wanted to try it, so I got a small piece of tapa and printed a design on it, just like my mother made them. My mother saw it and said it was not bad but I had to try it again. She showed me where to put the dots and how to apply the red paint (Interview with Monica, Airara village, 2001). 
SINUOUS OBJECTS

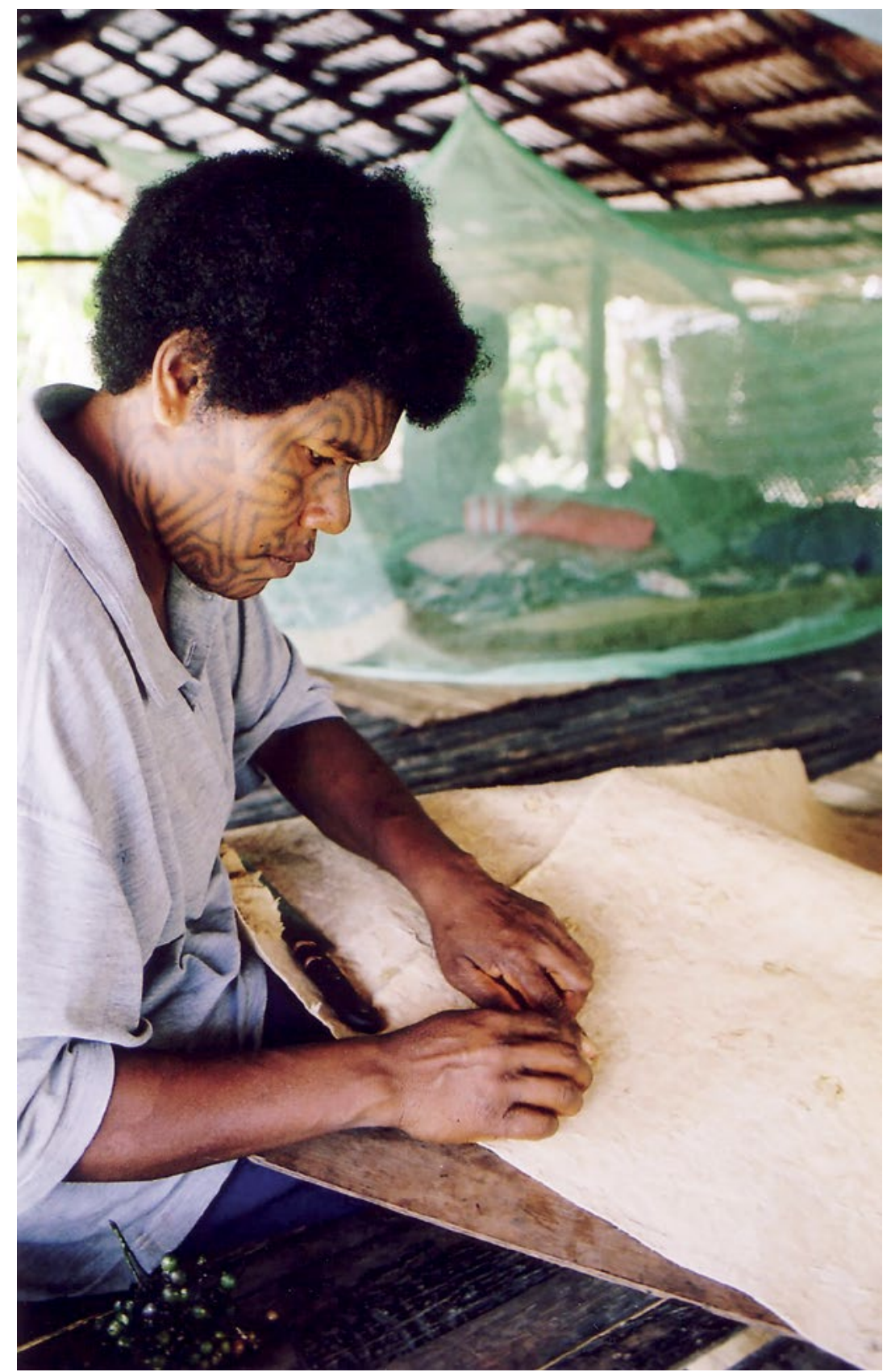

Figure 14. Monica patching holes in a piece of barkcloth

Source. Photographed by Anna-Karina Hermkens, 15 July 2004 
According to Monica, Maisin women have to make tapa. As she put it, 'It is our custom, we grew up with it, and nowadays tapa is our living. We make tapa, sell it, and get money with which we can buy things from the trade store' (Interview with Monica, Airara village, 2001). She insists that her daughters must learn the techniques of beating tapa and drawing designs. Linda, her second-eldest child, already knows how to beat tapa, although she does not do it as frequently as her mother.

Since I lived close to her, I often witnessed Monica drawing on her platform underneath the house, or occasionally on the elevated shelter. Maisin women make two types of designs: alienable designs and inalienable clan designs (evovi). Alienable designs are created in the mind before applying them, although women would also first draw their designs in the sand, trying them out without spoiling valuable barkcloth. Before setting out to make a new design, Monica would think about it and then 'draw' the design with four fingers on the white surface of the cloth. In this way, she would visualise her mental image of the design. The four fingers represent the four black lines that will meander and curve parallel to each other, creating three 'veins', of which the central one will be left white and the outer two filled with red dun. If satisfied, she would apply the design with black pigment, called $m i$. This implies that Monica already knew in advance what she was going to draw. This is very different from working without preconceived notions about the eventual outcome. As Monica explained, 'If I don't think about the design properly, I will make a mistake and spoil the design and the tapa' (Interview with Monica, Airara village, 2001). In addition to these alienable designs that result from women's imagination and creativity, sometimes inspired by designs in magazines, each of the 36 Maisin patrilineal clans has its own tapa designs, called evovi.

Maisin believe that when emerging from a hole in the Musa area, each clan ancestor brought his clan emblems (kawo). Clan emblems can vary from types of magic, social conduct and fire, to drums, dancing gear and tapa designs (evovi). The tapa clan designs are named and are often figurative, representing mountains, animals or specific artefacts that relate to the clan ancestor's travels and his claims on land, animals and artefacts. As such, clan tapa contains information about ancestral journeys, land claims and relationships between specific clans (see further Hermkens 2013). 
While especially men control the narratives dealing with the journeys associated with particular landmarks, the knowledge concerning the manufacturing of clan designs is in the hands of women, who transfer this knowledge and craft from mother to daughter and from mother-inlaw to daughter-in-law. In designing a clan's identity, women are crucial. They control the knowledge of the designs and their manufacture through which the clan itself is reproduced. Gendered forms of knowledge, power, affiliation, differentiation and identity are not only intertwined and expressed through particular types of tapa, they are also manipulated through tapa. The prohibition on wearing another person's clan design exemplifies this, since to do so would simultaneously denote a claim to land.

Both types of designs are drawn in black and coloured in with red pigment. Among the Maisin, the manufacturing of pigment was, as in other Pacific cultures, 'a magico-symbolic process' (Teilhet 1983: 49). In the past, the manufacturing and use of the red pigment (called $d u n$ ) was bound by rules and taboos. Unlike the black pigment, the red dye was mixed and boiled inside the house in a separate clay pot, which was not used for cooking food. Small children and men were not allowed to look at it or come near it. The view was that men's external bodily substances would 'spoil' the paint by causing it to 'dry up' or making it 'less red' and thus contaminate the dye because their substances are 'matters out of place' (Douglas 2004: 50). While working with the dye, women were secluded from the rest of society, not allowed to eat and drink or have sexual intercourse (Barker 2008: 114). They also had to speak quietly and, out of respect and fear of 'spoiling' the paint, they would refer to the dye as tambuta or taabuta, meaning 'red blood'. Since the ingredients of the dye have to be boiled and the resulting dun had to be applied when it is still warm, the association with living blood becomes more apparent (Figure 15). The ancestral clan designs depicted on tapa cloth can be seen as representing the male part in the conception of clan tapa; the red dye refers to the female blood that is necessary to complete it and make the design (and cloth) alive. Through the designing and painting process, a woman thus gives birth to an entity of cloth, thereby reproducing the patrilineal clan and its ancestral origins. This symbolised production of new life connects the ability to design and paint tapa with

5 Taa means blood, and buta is another word for $m u$, which means red or ripe. Today, the manufacturing of the red dye may be performed in public and children are allowed to sit with their mothers when applying it on the tapa cloth. 
the character of womanhood. Only strong, initiated, mature and sexually active women were believed to be able to handle the paint. Although today, while men are entering the production of barkcloth, they still avoid processes involving dun (see also Forshee 2001: 32). Moreover, only women have the prerogative associated with drawing and painting clan designs. As such, the significance of women reproducing the clan by drawing and painting clan designs on barkcloth continues. This is striking, as it is generally believed that Melanesian women do not produce the important symbols of their community, as this is seen as the prerogative of men (Teilhet 1983: 47).

In short, the specific gendered time and space involved in making tapa and learning about tapa, the arduous beating and pounding of tapa, and women's posture while making, drawing and painting tapa-sitting for hours unsupported with the legs stretched out - are all strongly connected with notions about how women should physically behave, their work ethos and their responsibilities. Women who do not make tapa are considered lazy and sometimes even 'bad' housewives, as they do not provide for their families. In this way, tapa plays an important role in local sexual politics, in which both women and men depend upon each other.

Significantly, making tapa defines especially the female body, both spatially and physically. It is connected with women's bodies and their minds, at the same time producing Maisin women who produce and reenact Maisin sociality through the making of tapa. This performativity is embodied, with both cloth and women becoming and being part of each other's substance (Hermkens 2015). It may thus be tempting to argue that, due to women's production of and intimate connection with tapa, this 'cloth' can be considered as 'women's wealth' or as women's property (Weiner 1989). In the next section, I will elaborate on Maisin exchanges and in particular on objects like tapa and the values that are exchanged, followed by an analysis of the commodification of tapa and how this affects the intimate relationship between women and tapa cloth. 
SINUOUS OBJECTS

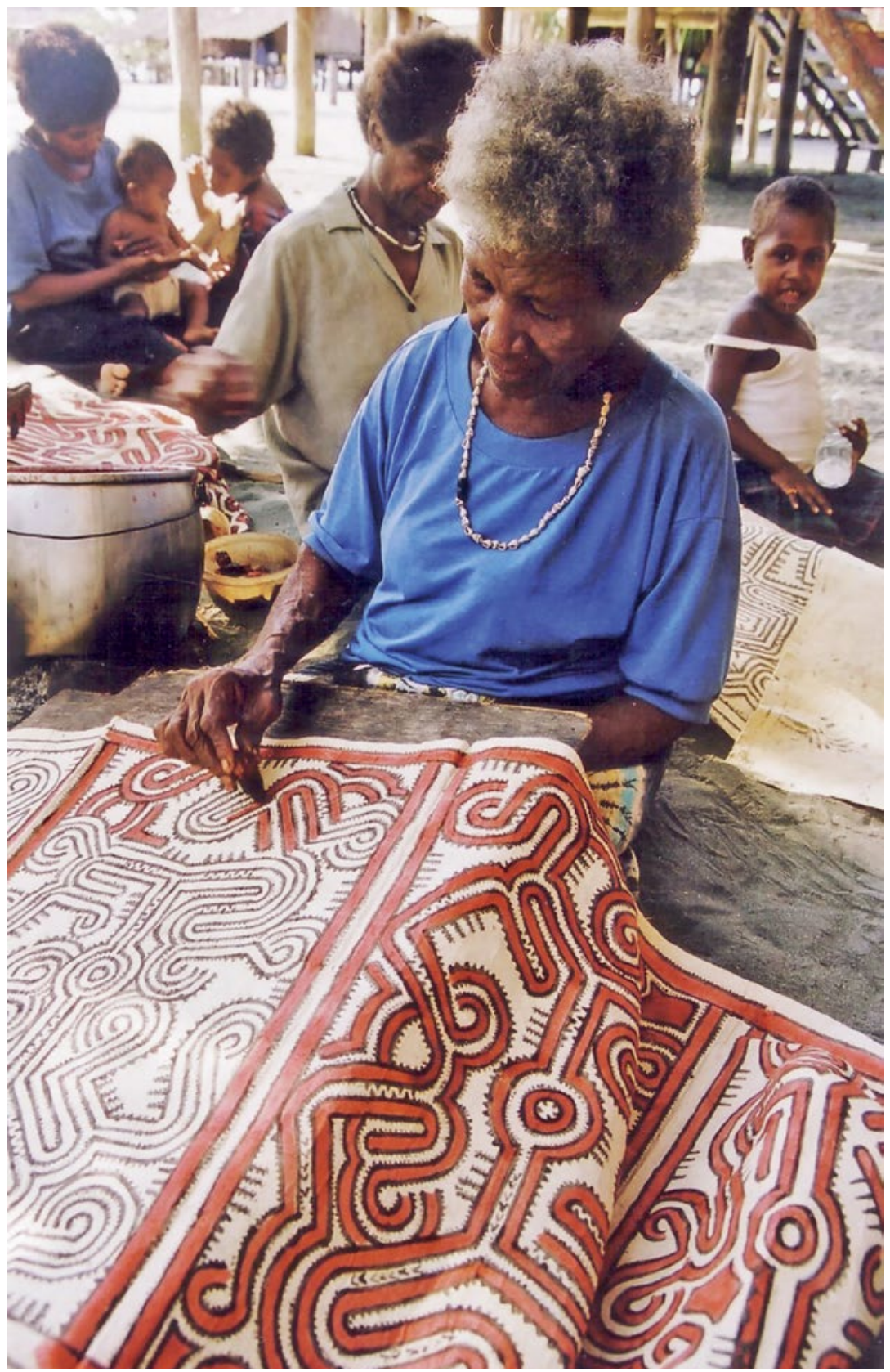

Figure 15. Mildred painting a piece of tapa with red pigment that is kept warm on a fire

Source. Photographed by Anna-Karina Hermkens, 17 April 2001 


\section{Objects and values of exchange}

Among the Maisin, the necessity to give plays a paramount role in everyday life and is the core of the organisation of social relationships. The necessity to give is called vina, and is one of the most dominant concepts of Maisin ways of living and thinking. Maisin describe this principle of reciprocity as 'exchanging' and 'compensating', or 'paying back'. It means that if someone gives you something or helps you, you are obliged to give a return gift. This return gift has to at least equal the value of the received gift and ideally overtop it.

Each occasion has its proper vina response (see also Hermkens 2013). If a person helps you in the garden, you give him or her raw food. If, due to a death, an area has to be 'cleared', or made accessible again, women will cook food together and share it with the deceased's relatives. If a husband belts his wife, her uncles (her mother's brothers) may demand compensation (food or money), and her brothers may seek revenge on her husband. In the past, but also more recently, a daughter was sometimes given as vina to marry a young man if he had helped her father or her clan enormously. And if a person falls and his or her in-laws or affines show their respect by throwing themselves on the ground as well, this person will have to compensate the in-laws by giving them food (or money). After a person has received a great amount of help or respect from other people, relatives or in-laws, he or she is compelled to make a return gift or compensation, referred to as vina. If, for example, someone has fallen from a coconut tree and is carried back to the village, this person will have to compensate his carriers and prepare a 'washing shoulders' (siva veyowi) ceremony. He or she will raise a pig and prepare enough food for this occasion to feed the people and their clans who helped him or her. Enough pots of cooked food (containing vegetables, fish and pig meat) have to be prepared in order to be presented to the helpers. In the past, the helpers' shoulders' would be washed with pig fat, thereby symbolising the work they had done and the compensation they would receive. In short, vina exchanges take place every day and during various occasions. Moreover, it encompasses and exceeds the boundaries of the various anthropological analytical distinctions of exchange. For Maisin, vina encompasses all formal and informal exchanges between individuals, groups of people and clans. This means that both a bride-price payment, as well as the sharing of food to compensate someone for his or her aid, is referred to as vina. 


\section{Daily life exchanges}

In daily life, exchanges or practices of sharing take place between husband and wife and the immediate family, the affines. For example, a woman will work on her husband's land, and in exchange he will give some goods to her family. In a similar way, she has to take care of his parents and provide them with the things they need. These exchanges are not always without comment. As many Maisin men will state, they prefer to get married to girls from a distant village, so they will not be burdened by having to provide their affines with gifts of food and money. In a similar way, a girl's parents will prefer her to marry within the neighbourhood so she, and her husband, can take care of them. Women preferably marry close to their father's clan as well. Such daily exchanges between family members also take place between the various households within one clan. Women bring food to their classificatory clan sisters or take care of their children while working in the garden. Both cooked and raw food is given, but also clothes and money. In addition, female clan members ask for goods like sugar and salt if present and, of course, betel nut is requested and shared within (and outside) the clan. They also help each other with making tapa, sharing the red pigment and giving tapa or wuwusi (tapa tree) to female clan members when they ask for it. Men within one clan may help each other when building a house or a garden fence. However, this kind of male exchange occurs far less frequently than the exchanges between women married into one clan.

In addition to exchanges that are part of the reciprocal relations established within groups due to marriage, there are also exchanges that exceed household and clan boundaries. Women often bring food or goods like clothes to relatives living in other clans, especially if they have been asked to do so. In addition, women exchange labour. If a woman helps a female friend or relative from another clan with an act such as making tapa, rolling up pandanus or working in the garden, she will receive food or other goods in return. Each time someone gives an item or gives help, this act of giving has to be balanced by the receiver and so on. This kind of daily sharing structures Maisin life and occurs especially between women. Men help each other as well, but this is predominantly within the clan. If outside help is needed, for example to build a house or to make a garden fence, a more formal and generous act of giving has to take place in order to 'pay them back' for their help. In general, this implies cooking food for the men (and women) who helped, or paying them with money. 
Importantly, the informal daily exchanges seem to especially create relationships between women, both inside and outside their husbands' clans. The advantage of these transfers is that during times of food shortage, these additional gifts of food aid women and their families to get by, although one cannot depend upon them either, as these practices of sharing food are not necessarily reciprocal. Moreover, the disadvantage of the necessity to give is that, if asked for, people have to give not only goods like sugar and salt, but also personal belongings. In order to prevent having to give away belongings (even money) people hide the possessions they want to keep.

Thomas Widlock (2013) points out that some of the practices described above are not necessarily reciprocal, but should be regarded as sharing. Instead of viewing these exchanges as either a covert form of market behaviour or as an extended form of reciprocity in line with Marshall Sahlins' (1988) work, he argues that sharing is a complex social phenomenon that makes rather specific requirements in regard to bodily copresence, relatedness and interaction. The challenge of sharing, he argues:

continues to be that people do share what they value, they share without receiving or even expecting returns, and they even—at times—value sharing itself. More specifically, they primarily value the sharing action by others while they themselves may avoid sharing by hiding things or at least by trying not to share at all times and under all circumstances (Widlock 2013: 12).

The daily exchanges I have described in the context of Maisin life have no format, but are the product of complex interactions that depend upon the relatedness of those involved and how they categorise each other, not just in terms of kinship but also in terms of amity (see also Widlock 2013: 20). Monica giving taro to a female friend without this person's asking, demanding a coconut from a relative, helping a neighbour to paint tapa without being asked to do so, and requesting a knife from a close friend are all part of daily complex interactions between people that inform how and what one may ask, demand and give, or not. When personal dynamics change, these practices of sharing will change too, while the more formal reciprocal exchanges between clans will continue as they were. This concurs with Widlock's observation that sharing is something different from reciprocity, as it requires 'particular actions by both provider and taker, accepting certain kin relations, responding to speech acts, and recognizing physical presence' (Widlock 2013: 21). 


\section{Barter and life-cycle exchanges}

In addition to daily practices of reciprocity and sharing such as outlined above, Maisin also engage in more sporadic and, at the same time, more formal exchanges with acquaintances and strangers in order to obtain specific, highly valued objects. Maisin women always have to make sure that tapa, string bags, pandanus mats and clay pots are present in the house. ${ }^{6}$ It is their responsibility to either make them or obtain them through barter. These female-produced objects are the major exchange items among and between the Maisin and neighbouring linguistic groups, and are used in daily practices of sharing, bartering, commodity and ceremonial exchanges. In the past, Maisin men would make engraved headrests, shell and bore-tusk necklaces, and they still make engraved lime sticks as well as the elaborate feather headdresses that visualise and embody patrilineal clan identity. Lime sticks, along with particular necklaces, are among the heirlooms cherished by both male and female clan members. Furthermore, men are responsible for organising formal exchanges and accumulating and distributing the objects in such exchanges. Along with money, pigs, raw and cooked food and store-bought goods, the main objects that are exchanged are tapa, pandanus mats and clay pots-objects that are all made by women. Unlike women, men do not produce things like tapa that embody and express the complementarity between men and women in constituting, personifying and expressing the patrilineal clan. What a man does is exchange his wife's (or wives') and female relatives' labour, which is embodied in the food they harvest and prepare, and in the objects they make or acquire through barter.

Maisin women predominantly give painted tapa in barter exchanges, which secures the acquisition of non-Maisin products like red shell necklaces (called wakèki) from Milne Bay, pottery from Wanigela women, and sometimes string bags from Biniguni women-objects

6 Maisin have always depended on the barter system with Ubir- and Onjob-speaking women living near Wanigela mission station to obtain the highly valued clay pots, which are only manufactured by these women (see Bonshek this volume). In the past, Wanigela women used to produce their own tapa, but at a certain point in time they started to rely on Maisin productions and the barter system. Maisin women use clay pots on various occasions. They are used as cooking pots at festivities and ceremonies, as ceremonial gifts, and at wedding ceremonies in which the bride has to break a clay pot from her groom's family. In addition, Maisin women use clay pots to barter with Biniguni women for string bags. They take second-hand clay pots up to the Biniguni mountain villages or Biniguni women take them back after having visited the coastal villages. 
that are used in both daily and ceremonial exchanges. ${ }^{7}$ Men make and sometimes barter for canoes with Miniafe or other people by giving tapa, which is made by their wives or other female relatives. Some of my male and female interlocutors stated that barter is vina, thereby making no distinctions between local and regional forms of exchange and between gift and barter exchange. However, not everybody included barter within the concept of vina, stating that barter was like 'buying' (kumas), because you know in advance what you are going to receive for your 'gift'. As one female interlocutor stated with regard to barter relationships with Wanigela women: 'Tapa tamème na wusu timènana' (We give them tapa, and they will give clay pots in return) (Hermkens 2013: 208).

Bartering occurs both between people who know each other, as well as between strangers. Sometimes women will barter with distant relatives or female friends who married into other villages. On other occasions, when women travel around or visitors come to their village, they will equally take the opportunity to barter their goods. Especially between previous exchange partners, extended exchanges may take place (see also Bonshek this volume). This involves trust and respect towards each other, since one depends upon the other to make the return 'gift' of the barter somewhat later. I witnessed Maisin women giving tapa to Wanigela and Biniguni women in order to receive respectively a clay pot or a string bag. These latter items were sometimes given in return months after the initial barter agreement had been made. In a similar way, Maisin women received clay pots for which they were supposed to give tapa sometime in the near future.

Men and women state that bartering is mainly women's work, especially if it involves objects made by women. But, even with bartering for canoes, which are made by men and regarded as their property, a woman has to be involved because she has to agree to the amount of tapa that is given in exchange for the canoe. In some cases, women individually negotiate to obtain their own canoe by giving tapa to the man who wants to barter

7 Wakèki or bagi are small variants of the red spondylus necklaces that are part of the kula exchanges among the Massim in Milne Bay. In the past, they were obtained through trade with Goodenough Island via the Mukawa people. Since Maisin men were working on plantations in Milne Bay from the 1910s until World War II, they were also bought at trade stores on, for example, Samarai Island, or received as gifts from Milne Bay friends. 
it. In other cases, the husband will seek support and agreement from his wife in order that she will make the agreed amount of tapa. It also occurs that deals to obtain a canoe are made between two men without any direct consultation with the wife who has to produce the counter (barter) gift. In these cases, especially when the amount of tapa is too big in relation to the size of the canoe, the wife's female relatives and friends help her design and paint it, at the same time criticising the deal made by her husband by gossiping about it.

Importantly, most of the objects used and obtained in barter are also part of life-cycle exchanges. In fact, barter makes these formal or ceremonial exchanges possible as it provides women and their households with the gifts to give. During life-cycle rituals, the giving of particular objects, such as tapa, mats and clay pots, are important in the 'objectification' of identities (Miller 1994). Gender and clan identities are constituted and relationships between groups are elucidated, revealing systems of respect and power. Especially a mother's brothers play an important part in these formal exchanges. They are responsible for the initiations of their sister's first-born child with whom they (the uncles) will develop a special relationship. And upon marriage, they will receive and distribute the bride price paid for their sister's daughter(s). The initiations, and the countergifts that have to follow, mark the special but also fragile relationship between the in-laws (for example, wife givers and wife takers). This relationship has to be maintained, and certain goods and respectful behaviour are expected and sometimes even enforced. A large part of the exchanges performed between Maisin are therefore performed between the wife-takers' and wife-givers' groups. During life-cycle rituals, tapa plays an important role as a garment that is given to wear to the child being initiated, the girl getting married (Figure 16) and the widow or widower ending her or his mourning period (Figure 17). But it also features as a gift to the affines, along with mats, clay pots, string bags and foods (Figure 18). 
3. WOMEN'S WEALTH AND MORAL ECONOMIES AMONG THE MAISIN

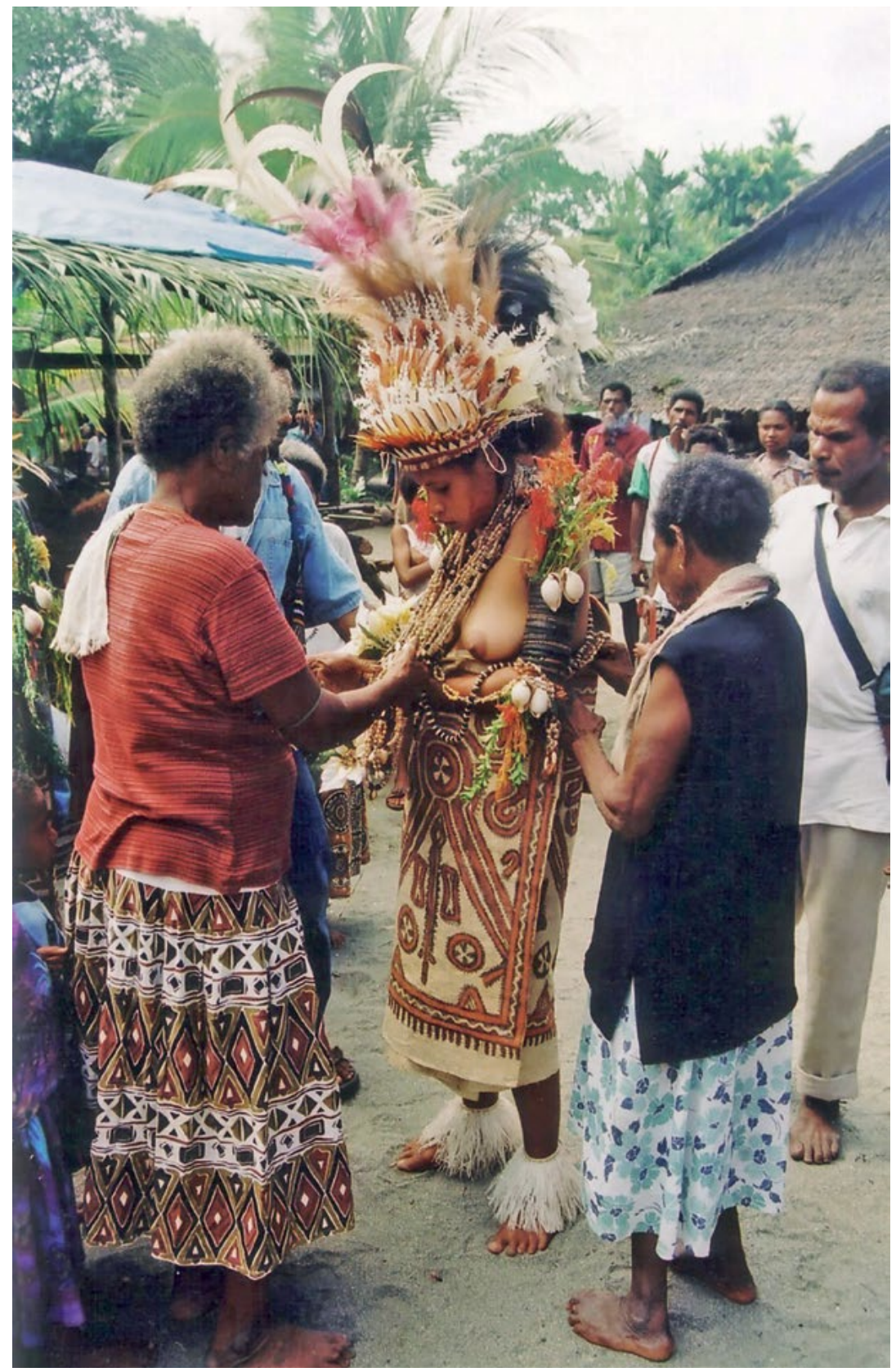

Figure 16. Georgina being dressed up in her father's regalia on her wedding day

Source. Photographed by Anna-Karina Hermkens, 31 December 2001, and used with Georgina's permission 


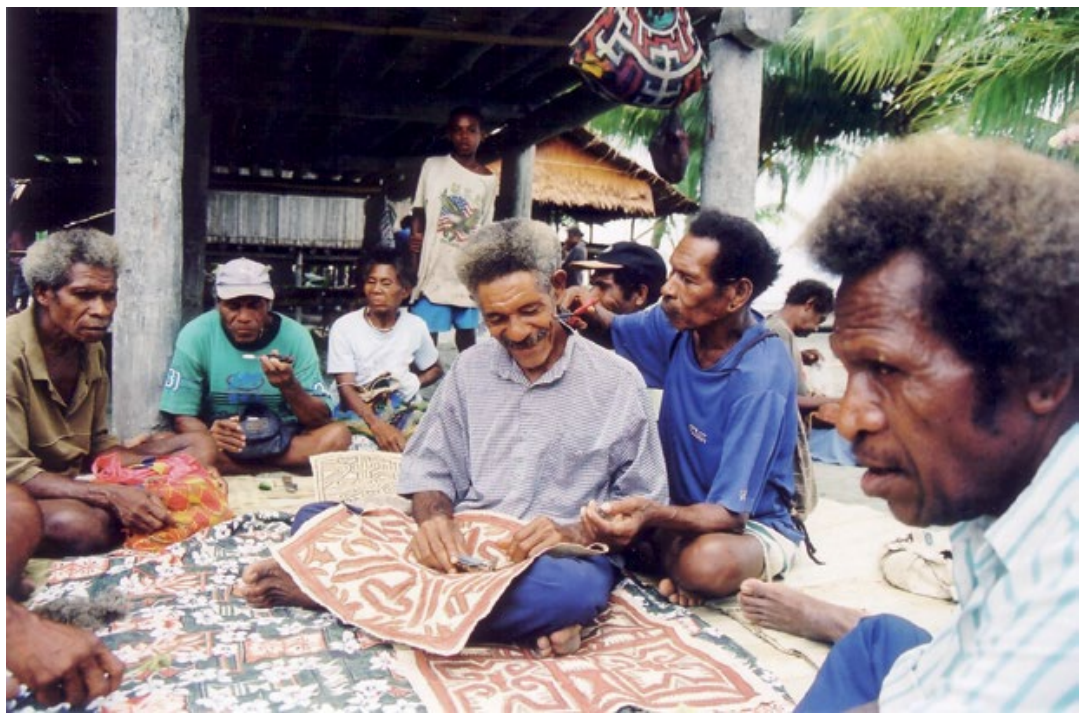

Figure 17. Abraham undergoing his 'end of mourning' ritual

Source. Photographed by Anna-Karina Hermkens, 25 December 2001, and used with the permission of the participants

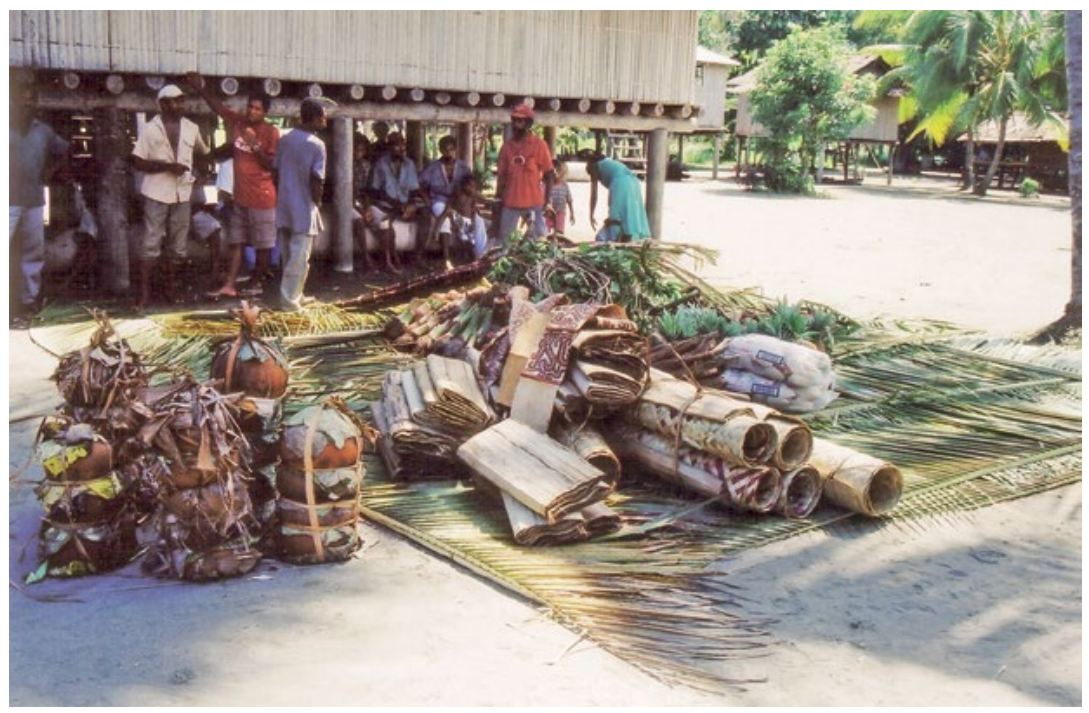

Figure 18. Pile of gifts for Georgina's in-laws, including pots, mats and tapa

Source. Photographed by Anna-Karina Hermkens, 31 December 2001 
So what we see in life-cycle rituals is men exchanging women's objects in the ongoing cycle of initiating or opening and balancing (marawawe) relationships between groups of people (for example, between the wifegiver's and wife-taker's clan), and redefining relationships between the living and the deceased (Hermkens 2013). At the same time, exchanges performed during life-cycle rituals mark the establishment of the individual's social person, referred to as mon seraman. This is similar to Orokaiva ceremonial exchanges, which mark social relationships and construct an individual's hamo (Iteanu 1995: 139; see also Hermkens 2015). However, while among the Orokaiva, land, pigs, taro plants and ornaments are essential components and partners in ritual exchanges (Schwimmer 1973: 5, 85-186), among the Maisin, women's work is referred to as buro seraman (work for which seraman is needed), which taps into and, at the same time, constitutes women's mon seraman. This labour is materialised in objects such as tapa, pandanus mats and clay pots that are essential components in exchange, along with pigs, taro and other kinds of food. This significant role of women's labour or women's objects as mediators in exchange is more reminiscent of Trobiand mortuary exchanges (sagali) where women's banana leaf bundles (doba) reflect the continuing ideological concerns of matriliny and human reproduction in Trobiand society, ensuring intergenerational social stability (Lepani 2012; Weiner 1976). Among Maisin, women's objects, like tapa, and women's labour in general reflect human reproduction in relation to the patrilineal clans, as well as important patrilineal kin and affinal relations. As such, women's wealth lies in the ability to give tapa, string bags, mats and pottery as gifts—objects that embody women's affective labour. So what happens when these objects are turned into commodities?

\section{Commodities, shifting values and gender relations}

Since the 1930s, several attempts have been made to commercialise tapa, both by foreigners and Maisin people themselves. The most important and recent attempt was made in the context of the antilogging campaigns in the early 1990s (Barker 2008). With the aid of a variety of organisations, the Maisin launched a lawsuit in the National Court to rescind licences that had been granted to logging companies to deforest Maisin ancestral lands. Meanwhile, a Maisin Integrated Conservation and Development (MICAD) organisation was established to provide oversight and a form 
of governance across the Maisin villages. Supported by Greenpeace, who dubbed its campaign 'Painting a Sustainable Future', and a Peace Corps couple who were stationed in Uiaku for two years, MICAD was to become a viable tapa-producing cooperative. The reason why tapa cloth was so attractive for activists was twofold:

First, it was a distinctive and attractive Indigenous art form that, with proper marketing, might provide Maisin with an alternative and sustainable source of income from selling off their ancestral lands. Second, it was made by women at a time when one of the few things international development and environmental agencies agreed on was the necessity to promote projects that improved both the economic lot and political clout of women in their communities (Barker and Hermkens 2016: 195).

Paradoxically, the commercialisation initiatives led to adverse effects on women's workloads, status and domestic situations. While some families and individual women benefited from tapa sales, in general, women's workloads increased dramatically. Tapa production increased considerably, while, at the same time, more food was needed to be grown and prepared for the waves of international and national visitors (Barker and Hermkens 2016: 196). In addition, the well-intended interventions by outsiders provoked much resentment among men, who claimed that they went against Maisin 'traditions'. A number of husbands even beat their wives in retaliation for participating in workshops and in overseas delegations (Barker and Hermkens 2016: 196). As a result, women's involvement in decision-making processes was limited. Moreover, the monopoly MICAD attempted to impose upon tapa production and purchases diminished women's control over the sales and proceeds of their production, ${ }^{8}$ with much of the profit eaten up to fund the travel of male executive members to and from Port Moresby (Barker and Hermkens 2016: 196). After the Peace Corps couple and Greenpeace representatives left, the international tapa markets collapsed, while women's position in the tapa business remained more or less the same.

8 MICAD developed a formula in which the size of the design (not of the tapa) determines its monetary value. In 2001-02 and 2004, MICAD paid in general K1.25 per square inch (the equivalent of AU\$1 at that time), while the Anglican Church managed to offer K2 or even more. The increase in tapa production at the time of the Greenpeace support also encouraged local people to set up a production line where some women would draw the designs while others would add the red pigment (Barker 2008). 
Despite the decline in tapa markets, people are still eager to sell tapa as it is one of the few means for them to make money. ${ }^{9}$ Regularly, groups of women can be seen painting stacks of tapa because one of their husbands suddenly decided to travel to the city in order to sell tapa. Female friends and relatives will help the wife with designing and/or painting in order to get the bulk of the tapa finished on time. On several occasions during my fieldwork in Airara, I witnessed Monica painting both day and night for a couple of days, desperately trying to finish the cloths in time for her husband, Clifford, to take them for sale on his regular trips to Alotau. Clifford would inform her about his intended 'business' trip some months in advance, urging her to make tapa for him to sell. During this time, Monica would alternate her duties as a mother and wife with beating tapa and drawing the alienable designs. But she would not yet apply the red pigment. In order to ensure the paint on the tapa is vibrantly red, which Maisin consider to be the norm as it signals vitality, she would only start painting a few days before Clifford was about to depart. This would happen as soon as word about the arrival of the cargo boat was heard. Monica then spent as much time as possible applying the red pigment to her pieces of tapa cloth. This always caused much stress, as it meant she had an enormous workload and had to continue painting during the night in order to get the pieces of tapa finished on time. Although he acknowledged his wife's workload and stress during these times, Clifford would never help her and she depended upon the goodwill of other women to help her finish the work in time. She would try to catch up on some much-needed sleep after Clifford's departure, which was difficult with five children and her elderly in-laws to take care of. Importantly, at the same time that Monica's and other women's responsibilities and work has intensified due to the ongoing commercialisation of tapa, they are losing their traditional control over tapa.

Maisin men are increasingly gaining control over tapa production, its destination and revenues, with tapa often no longer being considered part of its maker. While other objects made by women, such as string bags, mats and pottery, still belong to their female producers and barterers, tapa is gradually being alienated from the women who make and use it.

9 Tapa cloth has also been the chief means for churchwomen to raise funds to support their activities and the local church (see further Barker and Hermkens 2016). 
Married women in particular have to consult with their husbands before giving tapa away at exchanges, use it in barter, or sell it (Hermkens 2013). As Clifford stated:

My wife Monica cannot sell tapa without letting me know, but if I want to sell a finished tapa, I can do it without letting her know. She once gave three pieces to MICAD for them to sell, but they didn't pay her, and I am still angry with that. If she wants to give tapa to contribute to a mourning ceremony or bride-price payment, that's okay. But if I am here, we should talk about it (Interview with Clifford Taniova, Airara, 2001).

In short, the classification and value of tapa is changing. ${ }^{10}$

Arjun Appadurai's introduction to his edited volume The Social Life of Things (1986) already elucidated how things can move both within and between different classificatory categories. Maisin tapa exemplifies his thesis that it's more useful to think about 'things in a certain kind of situation' than about objects as being certain kinds of things (1986: 13). The commercialisation of tapa defines its value in economic terms, while as a gift in bride price or other ceremonial exchanges, it has value in social terms. However, the economic or commodity value of tapa seems to negatively impact various established 'regimes of value'-shared value standards (Appadurai 1986: 15) that facilitate the exchange of tapa. As Sylvester Moi, former chairman of MICAD, expressed:

During the last MICAD meeting [in 2002], several board members expressed the view that few tapa trees had been planted because MICAD had given so few new orders. This signals the fact that the traditional value of tapa is changing towards a commercial value only. Before, people had heaps of tapa in their houses so that they could give them during initiations and other festivities. Now, little tapa is given during such occasions. Also, less tapa is being used in barter. I feel sorry about this, especially when I see the tapa hats and bags that are being made. People perceive tapa as a cash-crop, a way to make money. But tapa constitutes an important part of our traditions. This seems now to get lost (Interview with Sylvester Moi, Ganjiga village, 2001).

Wanigela women who want to barter their clay pots for Maisin tapa, share Sylvester Moi's concern that tapa is losing its traditional value in gift and barter exchange. Instead of the traditional 'one pot in exchange for one

10 Importantly, clay pots are also no longer regarded as a woman's individual property if they were bought with money. In these cases, male and female informants stated that the object belongs to the family. 
tapa', their Maisin counterparts want more pots or even cash and, as such, Wanigela women are confronted with changed value standards on the Maisin's side. The result is that traditional regimes of value in the context of barter have turned into clashes of classification and incoherent value systems, resulting in tensed barter conditions and frustrations on the Wanigela side (see further Bonshek this volume).

Obviously, the shifting classifications and values of tapa in both gift and barter exchange imply a struggle over control. Following Appadurai on the interplay between politics and value (1986: 56-58), in her article on hierarchies of values at the Cambodian Angkor Wat temples, Lindsay French states, 'it is in the struggle to impose a particular system of classification ... that hierarchies of value are established and the politics of classification and evaluation are revealed' (1999: 173). The struggle over the classification and value of tapa amongst Maisin foremost reveals the power relations between gendered persons with respect to objects like tapa.

As Renée Hirschon in her edited volume Women and Property - Women as Property argued, 'property is a crucial indicator of the balance of power between women and men' (1984: 1). The quote from Clifford with regard to his wife giving away and selling tapa shows how men increasingly seek to control the commodity value and the revenues of tapa, thereby alienating women from the tapa they make. This alienation also occurs at another level with Maisin elders refusing to commodify clan tapa and clan designs, and to commercialise the alienable general designs outside of Papua New Guinea. At several international occasions, such as the exhibition of tapa at the Berkeley Museum in 1995, and the experimentations of Monica and two other Maisin women with tapa designs at the Philadelphia Fabric Workshop and Museum in 1997 (Hermkens 2013: 304, 317-19), Maisin elders agreed that the individual artists should not be revealed to the public as tapa belongs collectively to the Maisin. In these instances, Maisin elders and the community at large were concerned that women like Monica may gain advantage through exposure and recognition of their individual work. At the same time, offers to commercialise tapa designs, by the outdoor company Patagonia, have been turned down as elders are afraid they will lose control over 'Maisin' designs. In these instances, where individual gain and the loss of control over Maisin tapa designs are to be averted, Maisin tapa is no longer regarded as a woman's individual, a family's or clan property, but as Maisin cultural property (Hermkens 2013: 325). 
According to Strathern (1984: 165), objects such as tapa may be owned and therefore disposed of, but they are not alienable, as the labour that produced these objects remains part of the producer and, when given away, this labour has to be compensated for. As described earlier, women's objects like tapa in vina are not about exchanging wealth in an economic sense, instead they deal with exchanging and maintaining social life. The objects made and given by women are closely intertwined with all facets of Maisin life, and as such constitute vital and essential values related to daily life and birth, initiation, marriage and death. One could label tapa as 'women's wealth' (Weiner 1989), but in fact this would be too narrow a classification. Ultimately, it is about the complementarity of Maisin gender relations and the significance of women's work (buro seraman) in the procreation of each patrilineal clan as materialised in the making and wearing of clan tapa. Along the same lines, tapa is also not women's property, but the product of Maisin sociality as a whole. When alienable tapa becomes commodified, it is no longer valued as women's labour enmeshed in the social order achieved through longterm gift exchange, but valued as a product of women's labour. Although the revenues from tapa may be used for gifts, thus once again mediating relationships between people, it does seem that the commodification of tapa has changed its social value and its significance in creating and maintaining social balance through gift and barter exchange. From a Marxist perspective, this would also suggest that women's labour becomes objectified in tapa as a commodity. More fundamentally then, it is not tapa that is subjected to reification, but women themselves, 'whose own lifemaking activity, their labour power, is taken from them and represented in a coercive commodity form' (Haraway 2008: 175). Women thus become the commodity form (Haraway 2008: 175). In her reflection on Anglofeminist theory, Donna Haraway points out that within particular streams of thought, women do not suffer reification in the way Marx describes the process for the worker. Instead they face a much worse fate.

In masculinist sexual orders, woman is not a subject separated from the product of her life-shaping activity ... She is a projection of another's desire ... There is nothing of her own for her to reappropriate; she is an object in the sense of being another's project (Haraway 2008: 176).

This particular framing obviously takes away all agency women have as well as their desire. But Maisin women do have agency and desire in determining and influencing the barter and, perhaps more indirectly, the commodity value of tapa. Moreover, I think it is important to rethink 
materiality (both in objects and gendered bodies) beyond mere economy and capitalism, and acknowledge local epistemologies and value 'systems' while still being able to compare the material consequences of particular values and ethics (see also Alaimo and Hekman 2008: 7-8). Women like Monica are not just subjected to reification, they are also empowered through the responsibility, joy, love and sentient relationship they develop in the processes of making, wearing, giving, bartering and selling tapa. Contemplating a different, more intimate view of value reveals that perhaps the greatest value of tapa lies not in its conceptually bounded significance as a cultural artefact and object of exchange, but rather in its being a creative practice that nurtures both a woman's family and herself. This nurturing relates to a woman's ability to provide and care for her family via tapa, but also stems from the correspondence between tapa matter and her own mind and body. And perhaps, for women like Monica, this intimate correspondence between matter, body and mind, and the continuous drive to recreate this experience and create tapa, is at the heart of what is, and should be, valued most.

\section{References}

Addo, Ping-Ann. 2007. 'Commoner Tongan Women Authenticate "Ngatu Pepa" in Auckland'. In Hybrid Textiles: Pragmatic Creativity and Authentic Innovations in Pacific Cloth, ed. Heather E. Young Leslie, Ping-Ann Addo and Phyllis Herda. Special issue of Journal of Pacific Arts 3(5): 60-73.

- 2013. Creating a Nation with Cloth. Women, Wealth, and Tradition in the Tongan Diaspora. Volume 4. Association for Social Anthropology in Oceania (ASAO) Studies in Pacific Anthropology. New York and Oxford: Berghahn.

Alaimo, Stacy and Susan J. Hekman (eds). 2008. Material Feminisms. Bloomington: Indiana University Press.

Appadurai, Arjun (ed.). 1986. The Social Life of Things: Commodities in Cultural Perspective. Cambridge: Cambridge University Press.

Barker, John. 2008. Ancestral Lines: The Maisin of Papua New Guinea and the Fate of the Rainforest. Toronto: Broadview Press. 
Barker, John and Anna-Karina Hermkens. 2016. 'The Mothers Union Goes on Strike: Maisin Women, Tapa Cloth and Christianity'. In Gender and Christianity in Melanesia: Towards a Unified Analysis, ed. Michelle MacCarthy and Annelin Eriksen. Special issue of The Australian Journal of Anthropology 27(2): 185-205. DOI: 10.1111/taja.12193.

Carrier, James. 1995. Gifts and Commodities: Exchange and Western Capitalism since 1700. New York, London: Routledge.

Choi, Hyaeweol and Margaret Jolly (eds). 2014. Divine Domesticities. Paradoxes of Christian Modernities in Asia and the Pacific. Canberra: ANU Press. Online: press.anu.edu.au/publications/divinedomesticities (accessed 30 March 2017).

Colchester, Chloë (ed.). 2003. Clothing the Pacific. Oxford and New York: Berg Publishers.

Craig, Barry, Bernie Kernot and Christopher Anderson (eds). 1999. Art and Performance in Oceania. Bathurst: Crawford House Publishing.

Douglas, Mary. 2004 [1966]. Purity and Danger: An Analysis of Concepts of Pollution and Taboo. London and New York: Routledge.

Fajans, Jane. 1997. They Make Themselves, Work and Play among the Baining of Papua New Guinea. Chicago: The University of Chicago Press.

Forshee, Jill. 2001. Between the Folds: Stories of Cloth, Lives and Travel from Sumba. Honolulu: University of Hawai'i Press.

French, Lindsay. 1999. 'Hierarchies of Value at Angkor Wat'. Ethnos: Journal of Anthropology 64(2): 170-191. DOI: 10.1080/ 00141844.1999 .9981597$.

Godelier, Maurice. 1973. Perspectives in Marxist Anthropology. Cambridge: Cambridge University Press.

—. 1999 [1996]. The Enigma of the Gift. Chicago: University of Chicago Press. Trans from the French by Nora Scott. 1996. L'Enigme du don. Paris: Libraire Arthéme Fayard.

Graeber, David. 2001. Toward an Anthropological Theory of Value: The False Coin of our own Dreams. New York: Palgrave.

Gregory, C.A. 1982. Gifts and Commodities. London: Academic Press. 
Haraway, Donna J. 2008. 'Otherworldly Conversations; Terran Topics; Local Terms'. In Material Feminisms, ed. Stacy Alaimo and Susan J. Hekman, pp. 157-187. Bloomington: Indiana University Press.

Hermkens, Anna-Karina. 2007. 'Church Festivals and the Visualization of Identity in Collingwood Bay, Papua New Guinea'. Visual Anthropology 20(5): 347-364. DOI: 10.1080/08949460701610589.

- 2010. 'The Gendered Performance of Cloth, Ritual and Belief'. In Religion and Material Culture: The Matter of Belief, ed. David Morgan, pp. 231-246. London and New York: Routledge.

—_. 2013. Engendering Objects: Dynamics of Barkcloth and Gender among the Maisin of Papua New Guinea. Leiden: Sidestone Press.

—_. 2015. 'Mediations of Cloth: Tapa and Personhood among the Maisin in PNG'. Gender and Person in Oceania, ed. Anna-Karina Hermkens, John Taylor and Rachel Morgain. Special issue of Oceania 38(1): 10-23. DOI: 10.1002/ocea.5070.

Hermkens, Anna-Karina, John Taylor and Rachel Morgain (eds). 2015. Gender and Person in Oceania. Special issue of Oceania 85(1).

Hirschon, Renée (ed.). 1984. Women and Property - Women as Property. London and Canberra: Croom Helm.

Ingold, Tim. 2013. Making: Anthropology, Archaeology, Artand Architecture. Oxon and New York: Routledge.

Iteanu, André. 1995. 'Rituals and Ancestors'. In Cosmos and Society in Oceania, ed. Daniel de Coppet and André. Iteanu. Explorations in Anthropology, pp. 135-164. Herndon, VA: Berg.

Jolly, Margaret. 1991. 'Gifts, Commodities and Corporeality: Food and Gender in South Pentecost, Vanuatu'. Canberra Anthropology 14(1): 45-66. DOI: 10.1080/03149099109508475.

—_. 2008. 'Of the Same Cloth: Oceanic Anthropologies of Gender, Textiles and Christianities'. Invited Distinguished Keynote Lecture for the Association of Social Anthropology in Oceania, The Australian National University, Canberra, 14 February 2008. 
2014. 'A Saturated History of Christianity and Cloth in Oceania'. In Divine Domesticities: Christian Paradoxes in Asia and the Pacific, ed. Hyaeweol Choi and Margaret Jolly, pp. 429-454. Canberra: ANU Press. Online: press-files.anu.edu.au/downloads/press/p298891/pdf/ ch162.pdf (accessed 31 January 2017).

- 2015. 'Braed Praes in Vanuatu: Beyond the Binaries of Gifts and Commodities'. In Gender and Person in Oceania, ed. Anna-Karina Hermkens, John Taylor and Rachel Morgain. Special issue of Oceania 85(1): 63-78. DOI: 10.1002/ocea.5074.

Knauft, Bruce. 2002 [1999]. From Primitive to Post-colonial in Melanesia and Anthropology. Ann Arbor: University of Michigan Press.

Lambek, Michael. 2013. 'The Value of (Performative) Acts'. HAU: Journal of Ethnographic Theory 3(2): 141-160. DOI: 10.14318/hau3.2.009.

Lepani, Katherine. 2012. Islands of Love, Islands of Risk. Culture and HIV in the Trobiands. Nashville, TN: Vanderbilt University Press.

LiPuma, Edward. 1998. 'Modernity and Forms of Personhood in Melanesia'. In Bodies and Persons: Comparative Perspectives from Africa and Melanesia, ed. Michael Lambek and Andrew Strathern, pp. 53-80. Cambridge: Cambridge University Press.

Mauss, Marcel. 1979 [1950]. Sociology and Psychology: Essays. London: Routledge \& Kegan Paul.

- 1990. The Gift. The Form and Reason for Exchange in Archaic Societies. New York, London: W.W. Norton. Original edition, Essai sur le don, first published 1950 by Presses Universitaires de France en Sociologie et Anthropologie.

Meyer, Anthony J.P. 1992. The Funerary Tapa-Cloths of the Nakanai from New Britain. Series: Océanie-Oceania, No. 11. Paris: Galerie Meyer.

Morgan, David (ed.). 2010. Religion and Material Culture: The Matter of Belief. London and New York: Routledge.

Morgain, Rachel and John Taylor. 2015. 'Transforming Relations of Gender, Person, and Agency in Oceania'. In Gender and Person in Oceania, ed. Anna-Karina Hermkens, John Taylor and Rachel Morgain. Special issue of Oceania 85(1): 1-9. DOI: 10.1002/ocea.5069. 
Miller, Daniel. 1994 [1987]. Material Culture and Mass Consumption. Oxford: Blackwell.

Sahlins, Marshall. 1988. Stone Age Economics. London: Routledge.

Schieffelin, Edward L. 1976. The Sorrow of the Lonely and the Burning of the Dancers. New York: St Martin's Press.

Schneider, Jane. 1987. 'The Anthropology of Cloth'. Annual Review of Anthropology 16: 409-448. DOI: 10.1146/annurev.an.16.100187. 002205.

_ 2 2006. 'Cloth and Clothing'. In Handbook of Material Culture, ed. Christopher Tilley, Webb Keane, Susanne Kuechler-Fogden, Mike Rowlands and Patricia Spyer, pp. 203-220. London: Sage.

Schwimmer, Erik. 1973. Exchange in the Social Structure of the Orokaiva: Traditional and Emergent Ideologies in the Northern District of Papua. London: C. Hurst \& Company.

Strathern, Marilyn. 1984. 'Subject or Object? Women and the Circulation of Valuables in Highlands New Guinea'. In Women and Property Women as Property, ed. Renée Hirschon, pp. 158-175. London and Canberra: Croom Helm.

—_. 1990 [1988]. The Gender of the Gift: Problems with Women and Problems with Society in Melanesia. Berkeley: University of California Press.

Teilhet, Jehanne. 1983. 'The Role of Women Artists in Polynesia and Melanesia'. In Art and Artists of Oceania, ed. Sidney M. Mead and Bernie Kernot, pp. 45-56. Palmerston North: Dunmore Press.

Weiner, Annette B. 1976. Women of Value, Men of Renown: New Perspectives in Trobriand Exchange. Austin: University of Texas Press.

—_. 1989. 'Why Cloth? Wealth, Gender and Power in Oceania'. In Cloth and Human Experience, ed. Annette B. Weiner and Jane Schneider, pp. 33-72. Washington DC: Smithsonian Institution Press.

—_. 1992. Inalienable Possessions: The Paradox of Keeping-While-Giving. Berkeley: University of California Press. 
Weiner, Annette B. and Jane Schneider (eds). 1989. Cloth and Human Experience. Smithsonian Institution Press.

Widlok, Thomas. 2013. 'Sharing: Allowing Others to Take What is Valued'. HAU: Journal of Ethnographic Theory 3(2): 11-31. www.haujournal.org/index.php/hau/article/view/hau3.2.003/383.

Williams, Francis E. 1928. Orokaiva Magic. London: Humphrey Milford.

-1940. Drama of Orokolo. The Social and Ceremonial Life of the Elema. Oxford: Clarendon Press.

Young Leslie, Heather E. and Ping-Ann Addo. 2007. 'Introduction. Pacific Textiles, Pacific Cultures: Hybridity and Pragmatic Creativity'. In Hybrid Textiles: Pragmatic Creativity and Authentic Innovations in Pacific Cloth, ed. Heather E. Young Leslie, Ping-Ann Addo and Phyllis Herda. Special issue of Journal of Pacific Arts 3(5): 12-21. 
This text is taken from Sinuous Objects: Revaluing Women's Wealth in the Contemporary Pacific, edited by Anna-Karina Hermkens and Katherine Lepani, published 2017 by ANU Press, The Australian National University, Canberra, Australia.

dx.doi.org/10.22459/SO.08.2017.03 